\title{
On Tone and Morphophonology of the Akan Reduplication Construction
}

\author{
Emmanuel Nicholas Abakah \\ University of Education, Winneba, Ghana
}

\begin{abstract}
Reduplication in Akan has received some discussion in the literature but all the studies have concentrated on some aspects of segmental processes that operate on the base to generate the output. In this paper, we study the morphological, segmental and tonal processes related to reduplicative construction in Akan. We demonstrate that on the basis of tonal perturbations which bases and reduplicative templates undergo, and the output tone melody of the reduplicated form vis-à-vis the tone melody of the base, we are able to tell the base from the reduplicant in the Akan reduplicative structure. We argue in the central portions of this paper that the reduplicant in Akan could be either prefixed or suffixed to the base and, in the course of further reduplication construction, it could be sited within the two constituent tokens of the original reduplicative output which serves as an unmarked base for further reduplication. This piece of information
\end{abstract}

\footnotetext{
Emmanuel Nicholas Abakah

Department of Akan-Nzema Education, University of Education, Winneba

P. O. Box 25, Winneba, Ghana

Phone: +233-244-732-172 / +233-208-767-783; Email: enabakah@yahoo.com
}

Received April 20, 2014; Revised September 1, 2014; Accepted October 20, 2014 
2 On Tone and Morphophonology of the Akan Reduplication Construction

counterexemplifies the assertion in the existing literature that in the Akan reduplication construction, the reduplicant is invariably prefixed to the base. In this paper, we study reduplication of verbs, adjectives, nouns, and lexical reduplication and demonstrate that words belonging to the same class behave tonally the same.

Keywords: Morphophonology, reduplicative template, retriplicant, requadruplicant, tonal perturbation, lexical reduplication

\section{Introduction}

Reduplication is fundamentally a morphophonological process "in which some part of a base is repeated, either to the left, or to the right, or, occasionally in the middle" (Spencer 1991: 13). Looking at it from the morphological standpoint, it is a kind of affixation process (Spencer 1991, Odden 1996, Kager 1999) but from the phonological viewpoint, the reduplicant, the copiable material, is underspecified for both segmental and prosodic properties. Spencer (1991: 10) asserts that the copiable material may be an entire word, a morpheme, "a syllable or sequence of syllables or simply a string of consonants (Cs) and vowels (Vs) which does not form any particular prosodic constituent (i.e., syllable, foot, morpheme, and so on)." McCarthy \& Prince (1994) refer to the copied material or the reduplicant as the phonological realization of some reduplicative morpheme that is phonologically empty, while Odden $(1995,1996)$ argues that reduplication copies only the segmental melody of the base minus the prosodic properties. Similarly, Kager (1999: 196) has posited that reduplication does not copy a prosodic constituent and for that matter it cannot be simply 'constituent copying' however it involves a prosodic shape invariant in the reduplicant, also referred to as a 
reduplicative template. Abakah, Caesar \& Ababila (2010) have demonstrated that reduplication in Akan copies only the segmental melodies of the base which receive their tone melodies by default. Reduplication appears to be language universal inasmuch as countless languages of the world operate it with identical grammatical functions and semantic readings.

It will be shown in this paper that in the Akan reduplication construction, the segmental melodies of the base are at times copied with some of their prosodic properties, especially tone and nasality, which process Abakah (2005a) refers to as cloning. It will be argued in the central portions of this paper that the reduplicant is attachable to the base either on the right or on the left in contraposition to the apparent axiom in the literature that, in Akan, the reduplicative affix is invariably attached to the base on the left. We shall also investigate how the three major word classes of verbs (plus phrasal verbs), adjectives, and nouns reduplicate in Akan within the context of morphophonological processes and tonal perturbations that occur in the course of the Akan reduplication construction. Moreover, our focus in this paper is to establish the site of the reduplicant and other non-base tokens in a reduplicative output involving these three major word classes, each of which will be dealt with in a separate section.

\subsection{Inventory of Akan Tones}

Akan is a two-tone language having two contrastive level tones, namely the high tone $(\mathrm{H})$ and the low tone $(\mathrm{L})$. The $\mathrm{H}$ in Akan has an allotone generally referred to as Downstepped $\mathrm{H}$, downstep for short, and is denoted by 'H. Two contrastive linked tones in Akan generate a contour/gliding tone if and only if the tone-bearing segments (TBSs), which may be $\mathrm{VV}, \mathrm{VC}$, or $\mathrm{CV}$, occur contiguously. Given this 
4 On Tone and Morphophonology of the Akan Reduplication Construction

circumstance, a contiguous occurrence of LH or HL in Akan will invariably give rise to a rising tone $(\mathrm{R})$ or a falling tone $(\mathrm{F})$, respectively.

\subsection{Tone-Bearing Units in Akan}

In many tone languages, the tone-bearing unit (TBU) is taken to be the mora. However, the syllable is the basic TBU in Akan in that the syllable and the mora in that language clash, the direct result of the fact that Akan does not have a heavy syllable (Abakah 2005a). In Akan, all vowels are TBUs. Preconsonantal nasal consonants, postconsonantal liquids, and word-final nonvowel sonorants are also all syllabic in Akan and are therefore TBUs. All the types of TBU attested in Akan, and discussed above, can be found in the words in (1) below.

(1) i. ò.kú.sú.bé.ń.tsí.ŕ

ii. jo.kwá.á.tsí.rí.kwá.á

iii. pr.à.pr̀̀̀.gù.rà.ǹ.ǹ

iv. tsì.tsì.à.j̀.kó.dó.ŕ 'byname of a clan'

'man of straw'

'fat and tall'

'amulet'

Abakah (2010) has also written about the inventory of the Akan tones and tone-bearing units but he has not devoted sub-sections to them, like in all his works on Akan tonology.

\section{Reduplication of Verbs ${ }^{1}$}

${ }^{1}$ Most of the ideas and examples throughout this section have been replicated from some of Abakah's works on Akan synchronic phonology, especially Abakah 
Reduplication of the verb in the Akan language semantically triggers multiple occurrences of the action specified by the verb (Abakah 2013).

Akan verbs are generally subcategorizable into classes on the strength of their syntactic and semantic properties as well as their underlying tone melodies. On the basis of underlying tone melodies, verbs in Akan are sub-classifiable into three subclasses (see Abakah 1993, 2003b, 2005a for a detailed study of tone-based classification of verbs in Akan): Classes I, II, and III verbs in Akan have H, HL, and LH melodies, respectively, in phonological representations. But, in the Twi varieties of Akan, especially Akuapem and Asante, the distinction between classes II and III verbs is neutralized in that verbs classified as II and III in Fante receive identical LH tone melody in phonological representations in Twi. In his study of Stative Verbs in Twi, Kalchofner (2000: 594) has also classified Twi verbs into two classes, I and II, anchored in the same lexical $\mathrm{H}$ and $\mathrm{LH}$ tone melodies, respectively. This classification ties in with Abakah's (1993, 2003b, 2005a, 2010) classification, even though there is no evidence that Kalchofner (op. cit.) saw or read Abakah's (1993) classification of Twi verbs in question. Let us briefly examine the data below on the three classes of verbs in Akan:

(2) Class I verbs (H-Toned)

\begin{tabular}{|c|c|c|c|c|c|}
\hline Fante & jí & tóń & tạ́m & $64 \hat{\varepsilon}$ & tcíńm \\
\hline Twi & jí & tóń/tơ ஹِ & tǻḿ & $6 \mathrm{x} \varepsilon$ & tcím \\
\hline Gloss & take & sell & lift & look & twist \\
\hline
\end{tabular}

(2013), in the cause of readers who might not have access to Abakah (ibid.) and other works such as Abakah (2012) and Abakah, Caesar \& Ababila (2010). 
6 On Tone and Morphophonology of the Akan Reduplication Construction

Class II verbs - HL in Fante; $\mathrm{LH}$ in Twi

\begin{tabular}{llllll}
\hline Fante & bísà & kásà & dạ́ǹ & mán & púsùẁ \\
Twi & bìsá & kàsá & dàní & màn & pùsú \\
\hline Gloss & ask & talk & turn & branch & shake
\end{tabular}

Class III verbs - LH Melody in all the dialects of Akan

\begin{tabular}{llllll}
\hline Fante & sùmáa & sùmáa & pìrá & kùrá & tøìrćẃ \\
Twi & sùmáa & sùmáa & pìrá & kùrá & tcỳ̀ré \\
\hline Gloss & hide & send & injure & save & write
\end{tabular}

Classes II and III verbs, as exemplified in the above data, are produced on HL and LH melodies, respectively, in Fante, while in the Twi varieties, those two classes of verb are both produced on $\mathrm{LH}$ melody as noted earlier. Despite the tonal difference observed in (2), that is, Fante and Twi having three and two classes of verb, respectively, on the strength of lexical tone melodies, I posit three classes of verb for all the dialects of Akan at the underlying level (ulevel) of representation so as to facilitate our analyses.

\subsection{Reduplication of Class I Verbs in Akan}

The briefest examination of data (2) reveals that there are two types of Class I verbs in Akan. These are (i) monosyllabic verbs with $\mathrm{CV}$ root structure and (ii) disyllabic verb roots with $\mathrm{C}_{1} \mathrm{~V}_{1} \mathrm{C}_{2}\left(\mathrm{~V}_{2}\right)$ structure but they both have a common denominator, the $\mathrm{H}$ melody. In all the dialects of Akan, any disyllabic verb that has CVC stem structure is underlyingly a $\mathrm{C}_{1} \mathrm{~V}_{1} \mathrm{C}_{2} \mathrm{~V}_{2}$ root but the $\mathrm{V}_{2}$ deletes, provided it is specified as [+High] and the preceding $\mathrm{C}_{2}$ has [+Sonorant] specification in its feature matrix (see Abakah 2004 for a detailed study). So, in all verbs with CVC stem structure in Akan, 
the $\mathrm{C}_{2}$ is redundantly sonorant. ${ }^{2}$ However, phonetic disyllabic verbs with $\mathrm{C}_{1} \mathrm{~V}_{1} \mathrm{C}_{2} \mathrm{~V}_{2}$ structure, whereby the $\mathrm{C}_{2}$ is specified as [+Sonorant], exist in the Twi varieties of Akan only. This is because Twi does not apply the deletion process in question rigidly. Let us study data (3) below for exemplification.

(3) a. Monosyllabic class I

\begin{tabular}{|c|c|c|c|}
\hline & Verb & Gloss & RED \\
\hline i. & sí & to build & sì-sí \\
\hline ii. & dá & to receive & dtà-dłí \\
\hline iii. & sứ & to cry & sù-sứ \\
\hline iv. & tớ & to bake & tù-tớ \\
\hline v. & tó́ & to share & t6ì-t6é \\
\hline vi. & sé & to say & sì-sé \\
\hline vii. & só & to hold & sù-só \\
\hline viii. & tó & to buy & tò-tó \\
\hline ix. & má & to give & 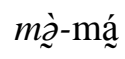 \\
\hline $\mathrm{x}$. & ká & be stranded & kà-ká \\
\hline
\end{tabular}

b. Disyllabic class I verbs

\begin{tabular}{|c|c|c|c|}
\hline & Verb & Gloss & RED \\
\hline i. & tcớń & to roam & tcì̀-tcíńn \\
\hline ii. & $\mathrm{p}_{\sim}^{\mathrm{j} i ́ m}$ & to hit & 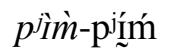 \\
\hline iii. & $\mathrm{k}^{\mathrm{w} u ́ r}$ & to roof & $k^{w} \grave{u}-\mathrm{k}^{\mathrm{w}} u ́ r$ \\
\hline iv. & $\mathrm{t}^{\mathrm{w}} \mathbf{u}^{\prime}\left(\dot{w}^{\prime}\right)$ & to throw & $t^{w} \grave{O}^{\prime}-\mathrm{t}^{\mathrm{w}} \dot{U}^{\prime}\left(\mathrm{w}^{\prime}\right)$ \\
\hline v. & tcérí & to delay & t6ì-t6éŕ \\
\hline vi. & fwóẃ & to peel & $f^{w} \grave{u}$-fwóów \\
\hline
\end{tabular}

2 See also Abakah (1993, 2003a, 2003b, 2004) for a detailed study of how wordfinal consonants come about in Akan. 
8 On Tone and Morphophonology of the Akan Reduplication Construction

\begin{tabular}{|c|c|c|c|}
\hline vii. & touéŕ & to lean on & t6yì-tøuéŕ \\
\hline $\mathrm{vi}$ & tớń & to sell & tờǹ-tóń \\
\hline ix & fắm & to attach & fàm-fắm \\
\hline $\mathrm{x}$ & páẃ & to select & pò-páẃ \\
\hline
\end{tabular}

It is evident from the above data that the prosodic features of tone and nasality inherent in the verb root/base vocalisms are not copiable in the reduplicative template italicised in the data. Since it is obligatory for every syllable in Akan to bear a tone at the phonetic level (p-level), the reduplicant receives a default tone which is redundantly the $\mathrm{L}$, seeing that Akan is a bitonal language as noted above. It is also clear from the above data that in Akan, if the base vocalism of the class I verb is [+High], then it is duplicated in the reduplicant as exemplified by (3a.i-iv) and (3b.i-iv). However, if the said base vocalism is specified as [-High, -Low], then it is raised to a [+High] vowel in the reduplicant, as in (3a.v-viii) and (3b.v-viii). The resultant reduplicant high vowel (V) agrees with the base vocalism in two dimensions of vowel harmony ( $\mathrm{VH})$, in being $[\alpha$ ATR] and in being [ $\beta$ Round], as (3a.v-viii) and (3b.v-viii) illustrate.

Nonetheless, if the base vocalism of the class I verb in Fante is specified as [+Low], then only the initial $\mathrm{C}$ of the base is copied as the reduplicant. In examples like (3a.x) and (3b.xii), for instance, ka and paw reduplicate as *k-ka and *p-paw, respectively. Thus, unattested CC sequences in the language, namely *kk and *pp, respectively, are generated. Where a disyllabic class I verbal base with a [+Low] vocalism terminates in a syllabic $\mathrm{N}$, it (the $\mathrm{N}$ ) copies together with the initial $\mathrm{C}$ of the base as (3b.ix-x) illustrate; that is, when fam and pan reduplicate, unattested CC sequences such as fm and $\mathbf{p m}$ occur as the reduplicants as in *fm-fam and *pm-pan reduplicated forms, respectively. Be that as it may, in either case, we 
observe generation of sequences of unattested $\mathrm{Cs}$ in the language. This elicits an epenthesis of a vowel to break the sequence in order to bring it in line with the phonotactics of Akan. The Fante variety of Akan consistently epenthesizes /à/ between the unattested CCs in question in the reduplicative template to generate the final output. Thus, just like all the examples in $(3 a, b)$ above where the base vocalism of the class I verb is [+Low], the pre-hyphen tokens of *kka, *p-paw, *fm-fam, and *pm-pan reduplicants receive the epenthetic /̀े, V, in the reduplicative template to generate the derived

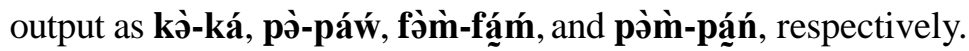

Hitherto, the high front $\mathrm{V}, / \mathbf{I} /$, has been wrongfully placed between a CC sequence unattested in all the dialects of Akan and analysed as A-raising. ${ }^{3}$ This sort of analysis is applicable to only the Twi varieties of Akan but it is wrongfully extended to cover Fante as well. This analytical extension seems to be influenced by the orthographical representations of three diverse Akan (Fante, Asante, and Akuapem) dialects each of which writes $/ \mathbf{I} /$ in that phonetic environment. Indeed, /I/ does not feature in the reduplicative template in this kind of reduplication in the Fante dialect at all and, for this reason, siting / $\mathbf{I} /$ in the reduplicant by a number of scholars, including Christaller (1875), Schachter \& Fromkin (1968), Obeng (1989), and Abakah (1993) is misleading. It is worth noting that throughout the phonology of Fante, /a/ in a class II or III verb raises to $[\mathbf{e} / \varepsilon]$, as (4b.i, v-ix) below and the subsequent data in this paper exemplify, whereas mid vowels raise to high vowels, as in (3a.v-viii)

\footnotetext{
3 Throughout the phonology of Akan, /a/ raises to mid tongue position, as (5i, iv, v) exemplify, whereas mid vowels raise to a high tongue position. Authors', (including Christaller's (1875), Stewart's (1962), Schachter \& Fromkin's (1968), Dolphyne's (1988), Obeng's (1989), and Abakah's (1993)) claim that /a/ shifts to $/ \mathbf{I} /$ in the reduplicant in Akan reduplication construction is not only bizarre but also counterintuitive.
} 
and (3b.v-viii) above, as well as in a number of examples scattered across varied data throughout this paper.

It is noteworthy that in Fante, the low vowel, /a/, in a class II or III verb, exhibits the following three general characteristics in reduplication production, it may

- be copied in the reduplicant as in kasa 'talk' which reduplicates as kasa-kasa or

- not be copied at all, like in the pre-slash output of guạn (which reduplicates as) gụ -guan.

- also be raised to mid vowel assuming [+/-ATR] shape, as in guẹ-guaan. ${ }^{4}$

Thus, we wish to repeat for emphasis: The theory that /a/ shifts to $/ \mathbf{I} /$ in the reduplicant in the Fante reduplication construction is bizarre, indefensible, and counterintuitive.

\subsubsection{Tone and Class I Verbs in Reduplication}

Reduplicative templates are redundantly toneless as noted above. It is discernible from data (3a) and (3b) above that the tones of all the verbal bases are not copied in the reduplicant. Consequently, all the reduplicant TBUs are realised on default $\mathrm{L}$, which makes it straightforward to tell between the base and the reduplicant. On the basis of the output tone melody of the Akan reduplication construction, we hypothesize, following Abakah (2005a) and Abakah, Caesar \& Ababila (2010), that the reduplicant of the class I verb is

\footnotetext{
4 Indeed, examples of these three characteristics of /a/ in Akan reduplicative construction abound in this paper and so readers can find more examples scattered in the various data below as they read on.
} 
regularly prefixed to the base in Akan.

\subsection{Classes II and III Verbs}

Classes II and III verbs reduplicate differently from class I verbs as the data below demonstrate:

(4) a. Class II verbs

\begin{tabular}{|c|c|c|c|}
\hline & Cl.II verb & Gloss & Reduplicated form \\
\hline i. & bứúkà̀m & outdo & 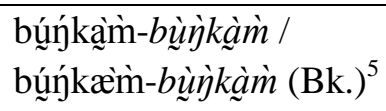 \\
\hline ii. & píńtoغ̇̀n & get near & 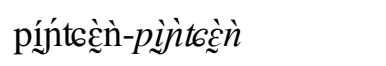 \\
\hline iii. & sámà̀n & summon & sámà̀ǹ-sàmàǹ \\
\hline iv. & táfìr & lick & táfìr-tàfir / tćfì-tèfî̀ \\
\hline v. & púsùẁ & shake & púsù-pùsù̀̀ \\
\hline vi. & nín & be pregnant & 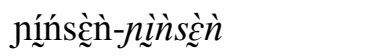 \\
\hline vii. & káḿfù & praise & káḿfù-kàmìù̀ \\
\hline viii. & tásì & collect & tásì-tàsì / tésì-tèsì \\
\hline ix. & pítsì & sprinkle & pítsì-pìtsì \\
\hline
\end{tabular}

b. Class III verbs

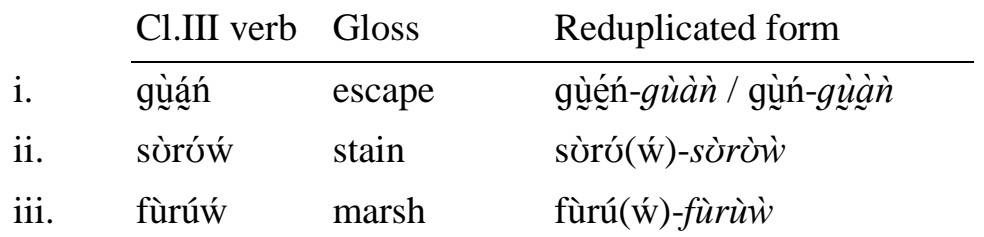

5 Bk. stands for the Boka variety of Fante. 
12 On Tone and Morphophonology of the Akan Reduplication Construction

\begin{tabular}{|c|c|c|c|}
\hline iv. & पìré'́́ & scrape & 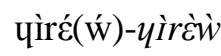 \\
\hline v. & kùrá & hold & kùré-kùrà \\
\hline vi. & mù̀náa & frown & mừnée-mừnà \\
\hline vii & tyìá & pay & tyìé-tyìa \\
\hline vii & wơrá & pour & wùré-wòrà \\
\hline ix. & sơmá & send & sùmદ́ǵ-sùmà \\
\hline
\end{tabular}

It is noticeable from the above data that in the reduplicative construction of the Akan classes II and III verbs, the underlying tone melodies of the bases of both classes of verb are retained in the leftmost token, whilst the rightmost token of the output receives the default L. It is evident that there is vocalic replacement in the left tokens in terms of (4b.v-ix), under class III verbs, whereas the basefinal vocalism is rather sited in the purported reduplicative suffix.

As regards the issue of the location of the nasal $\mathrm{V}$ in a reduplicative construction, Cahill (1985: 10) has observed that in Akan, "when a monosyllabic verb is reduplicated the copied vowel is not nasalized if the original vowel is a low nasal. If the original vowel is high, the nasal feature is also reduplicated." In contraposition to Cahill's (ibid.) observation (as examples 3a.iii, iv, and 4a.viii-ix demonstrate, regardless of the tongue height position) a base vocalism with an inherent nasal feature loses its nasality in the reduplicant for the reason that other things being equal, reduplication does not copy suprasegmental features in Akan. However, as Cahill (ibid.) has rightly observed: "... if the initial nasal consonant is reduplicated, the duplicate vowel is also nasal." Indeed, we repeat for emphasis that any [+Nasal] $\mathrm{V}$ which occurs in the context after a nasal $\mathrm{C}$ in a base (as we have just noted above) retains its nasality in the reduplicant, irrespective of its position in a morpheme, that is, 
whether word-initially or word-finally (see (3a.ix), (3b.i, ii, viii-x), (4a.i-iii, vi), and (4b.i, iii, vi) for illustration). This piece of research finding confirms, and gives credence to, Abakah's (2005a) and Abakah, Caesar \& Ababila's (2010) observation that even though, in Akan, reduplication copies only the segmental melodies minus their prosodic properties, at times the entire segmental and prosodic features of the base are cloned in the output of the reduplication construction (Abakah 2005).

Vocalic replacement in the bases that undergo reduplication is not unique to Akan. Odden (1996: 118) has affirmed that like Kikerewe, "Javanese has a pattern of vocalic replacement associated with reduplication." Hence, on the basis of the above explanation of postcopy phonological processes of A-raising and $\mathrm{VH}$ in V-Place ([CORONAL] and [RADICAL]) articulation features in Akan, we uphold the theory espoused in Abakah (2005a) replicated in Abakah, Caesar \& Ababila (2010) that reduplicants of classes II and III verbs in Akan are invariably suffixed to the base.

\subsection{Further Reduplication of Verbs}

Every Akan verb, regardless of its class could, in theory, be reduplicated ad infinitum to emphatically heighten the multiplicity, magnification, and amplification of the action it encodes. In practice, however, "the largest reduplicated form in use is made up of three identifiable parts" (Dolphyne 1988: 132). In this respect, the entire output of the original reduplicated form serves as a new base for further reduplicative construction. The following data, extracted from each class of the reduplicated forms in (3) and (4) above, illustrate this: 


\begin{tabular}{|c|c|c|c|c|}
\hline (5) & Cl.I CV Base & RED I & RED II & RED III \\
\hline i. & daí 'to get' & dzì-dłí & dłìłzí-dłìłzì & 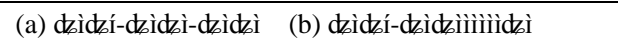 \\
\hline \multirow[t]{2}{*}{ ii. } & tớ 'to bake' & tò-tớ & tùtớ-tòtờ & $\begin{array}{ll}\text { (a) tờtớ-tờtờ-tờtờ } & \text { (b) tờtớ-tò̀tyiiiiiiìitờ }\end{array}$ \\
\hline & Cl.I CVC Base & RED I & RED II & RED III \\
\hline iii. & fiéw 'to kiss' & fì̀-fiéẃ & fr̀ffiéẃ-fìłfiè̀̀ & $\begin{array}{ll}\text { (a) fùfiéw-fì̀fièẁ-fìfièẁ } & \text { (b) fíffiéw-fíffièèèèè fièẁ }\end{array}$ \\
\hline \multirow[t]{2}{*}{ iv. } & kúr 'to roof' & kù-kúí & kùkúr-kùkùr & $\begin{array}{ll}\text { (a) kùkúŕ-kùkùr̀-kùkùr } & \text { (b) kùkúr-kùkùùùùùukùr }\end{array}$ \\
\hline & Cl.II Base & RED I & RED II & RED III \\
\hline v. & púsà̀ 'squeeze' & púsà-pòsà & púsà̀ườà-pòsàpòsà & púsà̀pờà-pơsàpơsà-pơsàpơsà \\
\hline \multirow[t]{2}{*}{ vi. } & tásì̀ 'gather' & tésì̀-tغ̀sì & tésì̀tèsì-tèsìtèsì & tésì̀tèsì-tèsìtèsì-tèsìtèsì \\
\hline & F-toned Cl.II Stem & RED I & RED II & RED III \\
\hline vii. & mán 'branch' & $\begin{array}{l}\text { (a) màḿ-màǹ } \\
\text { (b) màá-màn }\end{array}$ & $\begin{array}{l}\text { (a) màḿmàm-màmmàǹ } \\
\text { (b) màámàn-mààmàn }\end{array}$ & $\begin{array}{l}\text { (a) màámàǹ-mààmàn-mààmàǹ } \\
\text { (b) màámàn-mààmààààààmàn } \\
\text { (c) màmmmàǹ-màmmàǹ-màmmàn }\end{array}$ \\
\hline viii. & tséì 'listen' & $\begin{array}{l}\text { (a) tsèí-tsèì } \\
\text { (b) tsèétsèè }\end{array}$ & $\begin{array}{l}\text { (a) tsèítsèì-tsèitsèì } \\
\text { (b) tsèétsèè-tsèètsèè }\end{array}$ & $\begin{array}{l}\text { (a) tsèítsèi-tsèitsèì-tsè̀tsèì } \\
\text { (b) tsèétsèè-tsèètsèèèèè ètsèè }\end{array}$ \\
\hline viii'. & tsiè 'listen' & $\begin{array}{l}\text { (a) tsiétsìè } \\
\text { (b) tsìí-tsì̀ }\end{array}$ & $\begin{array}{l}\text { (a) tsìétsiè-tsiètsiè } \\
\text { (b) tsìítsiè-tsiìtsì̀ }\end{array}$ & $\begin{array}{l}\text { (a) tsiétsìè-tsì̀tsì̀-tsìetsiè } \\
\text { (b) tsiítsìe-tsì̀tsììììitsiè }\end{array}$ \\
\hline & Cl.III Base & RED I & RED II & RED III \\
\hline ix. & sìrá 'bless' & cìré-cìrà & cìrécìrè-cìrècìrà & $\begin{array}{l}\text { (a) cìrécìrè-cìrècìrè-cì̀ècìrà } \\
\text { (b) cìrécìrè-cìrècìrèèèèèècìrà }\end{array}$ \\
\hline$x$. & yiá 'steal' & $\begin{array}{l}\text { (a) पìé-qìà } \\
\text { (b) पî̀-पì̀̀ }\end{array}$ & 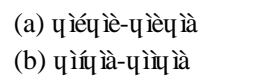 & 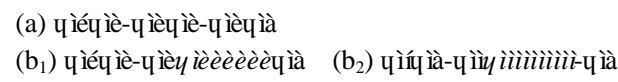 \\
\hline
\end{tabular}


Based on the output tone melody of reduplicated forms, the reduplicant of every class I verb, on the one hand, and every class II/III verb, on the other, are prefixed and suffixed to the base, respectively, as noted above. However, irrespective of class, the reduplicative template of a second reduplicated form (RED II) is incontrovertibly suffixed to the base, seeing that the rightmost token of the reduplicated form is L-toned signalling that it bears the default L. This is because, as noted above, all reduplicants or copiable units are toneless and, for this reason, they redundantly receive the default $\mathrm{L}$ at the phonetic stage. As regards the third copy (RED III) referred to as retriplicant in this paper, it is difficult to determine its affixal site, whether it (the retriplicant) is affixed to the reduplicant of the second reduplicated form on its right or in its middle. This is because it is as toneless as the reduplicant of the second reduplicated form. However, in the (b) examples the affixal site of the retriplicant is easy to determine in view of the fact that it is located at the boundary between the two halves of the reduplicative output of RED II.

Nevertheless, a close study of the alternative output of the third reduplicated form sited at the post-slash environment in (5) suggests that the retriplicant, italicised in the data above, is sited at the boundary between the rightmost and the leftmost tokens of the reduplicant of the second reduplicated form. It is noteworthy that the alternative version at the post-slash environment is used more often by Fante speakers than the pre-slash variety because it is used mostly in informal discourse situations. Inherent in it is a kind of infinite technique by which a $\mathrm{V}$ following the initial syllable of the retriplicant is lengthened as long as the breadth could support.

In reality, not all types of verb in Akan can have the post-slash forms of the third type of further reduplicative construction. As can be seen from (5) above, class II verbs do not undergo this kind of 
reduplication. So, founded on reduplicative construction involving verbs in Akan, which we have studied so far, the reduplicative template does not have a fixed affixal position. It could be prefixed, suffixed, or (in the case of further reduplication) fixed between the boundary between the base and the reduplicant of the first/original reduplicated form. These have been italicised for easy identification in the examples.

\section{Adjective Reduplication}

Reduplication of the adjective intensifies the semantic reading of the adjective and the degree of intensity is tied in with the number of times that it is reduplicated (see also Dolphyne 1988; Owusu-Ansah 1995; Amfo, Boateng \& Otoo 2007; Abakah, Caesar \& Ababila 2010). Like verbs, nearly all adjectives can be, in theory, reduplicated ad infinitum, depending upon the degree of intensity which the speaker intends to place on the semantic reading of the adjective. However, it is not always clear whether the lexemes in (6) are adjectives or nouns (Boadi 2010: 67). In the Asante variety of Akan, for instance, the noun is invariably affixed with a nominal suffix whereas the adjective does not receive any word class indicator affix. So, it is easy to differentiate between the following pairs: aniwu-o ('disgrace') and aniwu ('disgraceful'); ayırch ('grief') and ayircho ('grievous') etc. (ibid.). The Fante variety of Akan, from which the bulk of the data for this study were collected, does not have any differentiative indicators. All the same, the noun reduplicates once, whereas the adjective can retriplicate or requadruplicate. So, the lexemes in (6) below are all adjectives, not nouns. 


\begin{tabular}{|c|c|c|c|c|}
\hline (6) & Adjective & Gloss & RED I & RED II \\
\hline \multirow[t]{2}{*}{ i. } & è-jníwú & disgraceful & (a) èníwé-é!níwú & (a) èníwé-é'níwú-é'níwú \\
\hline & & & (b) ènìwè-èníwú & (b) èníwé-ènìwè-èníwú \\
\hline \multirow[t]{2}{*}{ ii. } & è-ní⿴囗łé & agreeable/entertaining & (a) ènírłzé-é'nírké & 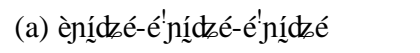 \\
\hline & & & (b) ènìdtè-èníácé & 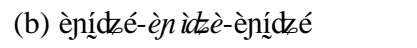 \\
\hline \multirow[t]{2}{*}{ iii. } & è-nítớ & embarrassing & (a) èníntué-é'jítỡ & (a) èníttué-é'níttớ-é'níttớ \\
\hline & & & (b) ènìtyè-ènítớ & (b) ènítué-ènittyè-ènítớ \\
\hline \multirow[t]{2}{*}{ iv. } & à-hớgưaáń & troublesome & (a) àhớgựán-á'hớgứáń & (a) àhỡgứáán-ấhỡgứáń-á'hỡgưaáń \\
\hline & & & (b) àhờgừànn-àhỡgứáń & 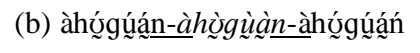 \\
\hline \multirow[t]{2}{*}{ v. } & à-kóńdó & appetising & (a) àkóńdwá-á'kóńdó & (a) àkóńdwá-á' kóńdwá-á' kóńdó \\
\hline & & & (b) àkj̀ǹdwà-àkóńdó & (b) àkóńdwá-àkj̀ndwà-àkóńdó \\
\hline \multirow[t]{2}{*}{ vi. } & è-hí & irritating & (a) èhíi-é'hí & (a) èhĩéhì-èhĩiéhì-èhĩé'hí \\
\hline & & & (b) èhì-éhí & (b) èhìéhì̀-èhìiéhì̀-èhìéhì \\
\hline \multirow[t]{2}{*}{ vii. } & è-bùfúẃ & annoying & (a) èbùfúw-ébùfúẃ & èbùfúw-èbùfúw-ébùfúẃ \\
\hline & & & (b) èbùfùw-èbúfúw & \\
\hline \multirow[t]{2}{*}{ viii. } & à-yìrc̀húẃ & disconsolate & (a) àuìrc̀hứw-áuìrc̀húẃ & àuìrc̀húw-áuìrèhów-áuìrèhóẃ \\
\hline & & & (b) àuìrz̀hờ-àyìrz̀húẃ & \\
\hline \multirow[t]{2}{*}{ ix. } & à-bơfớń & disgusting & (a) àbưfớn-ábùfớń & àbùfứn-ábòfớn-ábùfỡń \\
\hline & & & (b) àbòfờn-àbớfớń & \\
\hline
\end{tabular}


The reduplicants in the post-slash forms, labelled (b) under RED I, are obviously prefixed to the base on the basis of the output tone melody of the first token of a prefix, which is incontrovertibly the default $\mathrm{L}$.

A brief study of the phonological processes that operate during reduplication construction may facilitate comprehension of the segmental transmutations in the constituent tokens of the reduplicative output. In (6iii, v), for instance, glide formation occurs across the boundary between the base and the reduplicant which replicates across the boundary between the medial and the following final tokens. This is to be expected in all phonetic environments where a [+Round] $\mathrm{V}$ precedes a [-Round] vowel in the Akan phonology. In the case of an adjective base that begins and terminates in a vowel and a nonvocalic syllabic sonorant, $/ \mathbf{m}, \mathbf{n}, \mathbf{r}, \mathbf{w} /$, respectively, resyllabification occurs at the boundary between the two halves of the reduplicative output as (6iv, vii-ix) illustrate. Here, the first token's final syllabic sonorant resyllabifies to the onset position of the following onsetless $\mathrm{V}$ syllable. ${ }^{6}$ Needless to say, the resultant sonorantal onset ceases to be syllabic and accordingly loses its TBU status. The $\mathrm{H}$ which the nonvocalic syllabic sonorant inquestion bears is, as expected, transferred onto the nucleus of the new syllable because onsets are not tone-bearing in any tone language. In (6) the segments that undergo resyllabification are underlined at token boundary.

The vowel replacements in the derived outputs in (6) as in the other data scattered throughout this paper, is the direct result of obligatory vowel simplification process which comes about in the language whenever a sequence of nonidentical Vs occurs at the boundary between two words or morphemes. Invariably, the $V_{1}$ in a

\footnotetext{
${ }^{6}$ The onset and the nucleus of the resultant syllable are underlined in (6) and (6').
} 
$\mathrm{V}_{1} \# \mathrm{~V}_{2}$ or $\mathrm{V}_{1}+\mathrm{V}_{2}$ sequence deletes, if the $\mathrm{V}_{2}$ is specified as [+Low]. In Fante, the $V_{2}$ invariably spreads leftwards to the position that had previously been occupied by $\mathrm{V}_{1}$ to compensate for the $\mathrm{V}_{1}$-loss (see Abakah 2004 for a detailed study of this process in Akan).

Tonologically, when an underlying LH-toned adjective whose constituent $\mathrm{L}$ and $\mathrm{H}$ are singly linked and multiply linked, respectively, reduplicate, two interchangeable phonetic representations are generated under both RED I and RED II, as in (6i-v). In (6i.a, ii.a, iii.a, iv.a, v.a) under RED I, the lexical tone melody of the base is duplicated in the reduplicant with some modification brought about by a postcopy tone sandhi rule. Here, the $\mathrm{H}$ of the left token of the reduplicated form spreads rightwards to the initial $\mathrm{L}$ of the rightmost token and dislodges it. The displaced $\mathrm{L}$ floats and conditions the following $\mathrm{H}$ to receive a lower pitch value relative to a preceding H. In (6i.a, ii.a, iii.a, iv.a, v.a, vi.a) under RED I which constitutes an alternative phonetic output to (6i.b, ii.b, iii.b, iv.b, v.b, vi.b), respectively, it is evident that the reduplicant is produced on default L. It can therefore be argued that the left token of the reduplicative construction in (6i.a, ii.a, iii.a, iv.a, v.a) makes up the reduplicant while the right element is the base, thereby giving rise to prefixing reduplication.

\subsection{Comments}

We have seen in the reduplication of the verb in Akan above that a reduplicated verb can be further reduplicated. In this context, the entire output of the first reduplicated form constitutes the base for further reduplication. The adjective can also reduplicate more than once in Akan but with some difference. Here, the second reduplication structure (RED II) does not employ the entire output of 
the first reduplicative construct as its base; but, it is rather the original base of the adjective that copies twice or retriplicates, making the three constituents of the reduplicative/retriplicative output transparently distinct, unlike the verb whose three identifiable parts are really six, that is, the base plus its five copies. This basically means that the adjectival base in Akan duplicates or triplicates, depending upon the degree of intensity which the speaker intends to characterise the adjective. The reduplicated and retriplicated forms are listed in (6) above under RED I and RED II, respectively. In the cause of easy reference, we repeat (6) as (6') on the following page.

It is worth noting that in the forms under RED II (i.e., 6i.a, ii.a, iii.a, iv.a, v.a), the $\mathrm{H}$ of the base is copied twice, that is to say, it is retriplicated but with modifications not similar to those found in the forms under RED I. The cloned $\mathrm{H}$ spreads rightwards to the initial Ltoned TBU of the following token and displaces it. As noted in some other cases above and generally throughout the Akan tonology, a displaced L floating between two Hs redundantly imposes a pitchlowering effect on the $\mathrm{H}$ it precedes, thereby causing it to receive a lower pitch value than the $\mathrm{H}$ preceding it. So, both the reduplicative and the retriplicative templates are realised on identical tone melody.

A completely diverse tone melody features in the alternative phonetic forms, as in (6i.b, ii.b, iii.b, iv.b, v.b, vi.b) under RED II. Apparently, the retriplicant is sited between the base and the reduplicant of the output of RED I. A close study of the output tone melodies of RED I suggests that in the RED II output forms, the italicised copy is the second copy or the retriplicant. The segmental and tone melodies of the rightmost and the leftmost copies are so identical that telling between the base and the reduplicant is an uphill task, an almost impossibility. However, the fact remains that one of the tokens at the edges is the base whilst the other constitutes the 


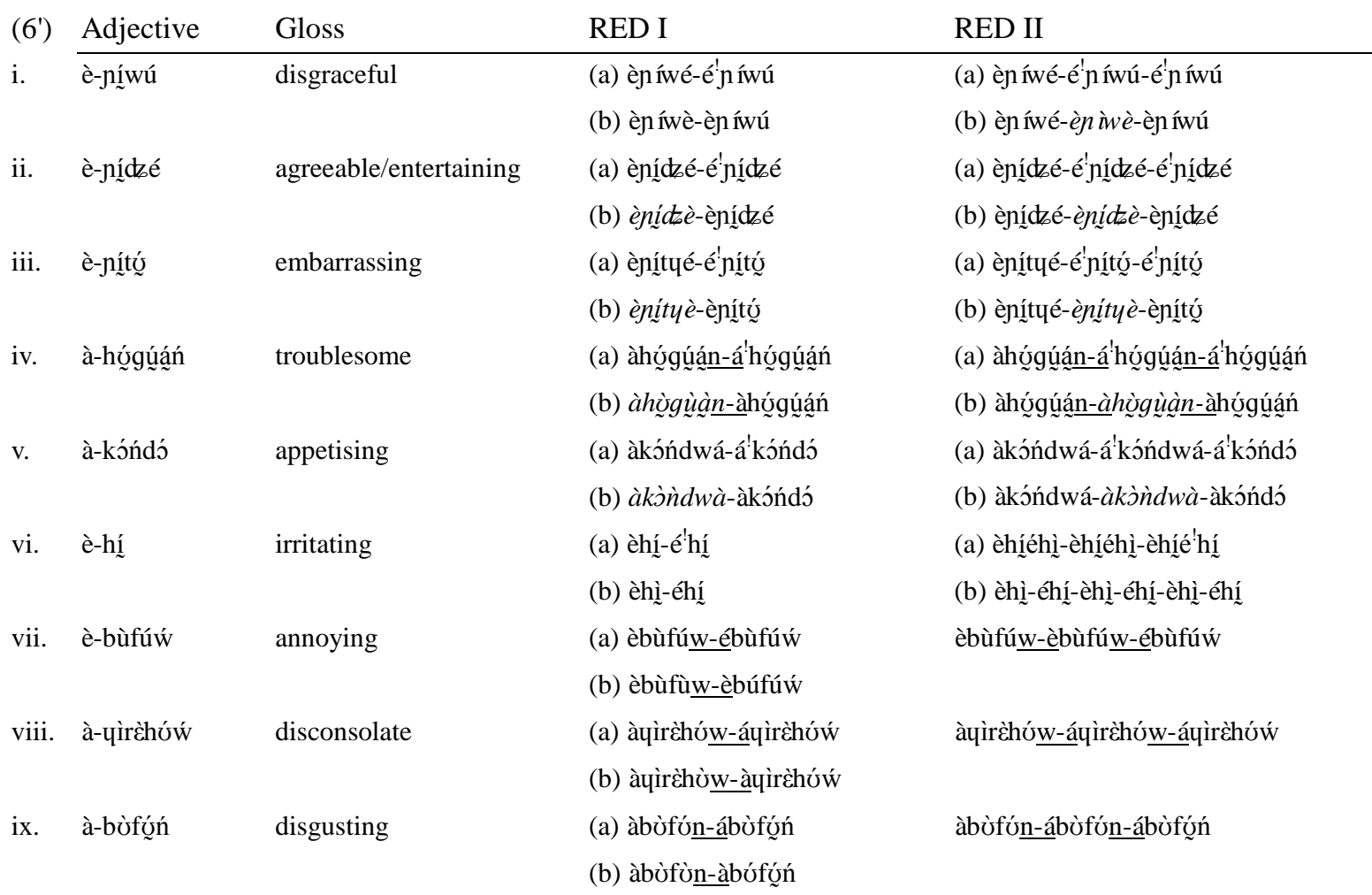


22 On Tone and Morphophonology of the Akan Reduplication Construction

reduplicant.

Plausible theories could be propounded with regard to the middle token of the RED II being the retriplicant. First, it could be presumed that the middle token copies only the segmental melody of the reduplicant which could be either the first or the third token, but it fails to copy its cloned tone melody, thereby remaining toneless throughout the derivation and accordingly receiving the default $\mathrm{L}$ at the p-level. It is therefore conceivable to assume that the retriplicant is the middle token, sited between the base and the reduplicant.

Two other reliable theories on the middle token of this type of reduplicative output being a recipient of the default $\mathrm{L}$ are possible. One theory resides in the hypothesis that both the segmental and tone melodies of the base are copied/cloned twice. This triggers a postcopy tone sandhi process to counterbalance the monotony of identical tone melody characterising all the tokens of the reduplicative construct. The said tone sandhi process involves the tone of the initial TBU of the third token which spreads leftwards through all the TBUs to the leftmost boundary of the middle token. Lack of tone perturbation on the middle copy of the base clearly suggests that the L-Spread was preceded by erasure of the cloned tone of the middle token. This explains why the middle token is produced on an L. The derivation below captures this account in graphic terms: 
(7)

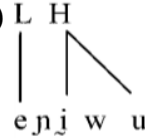

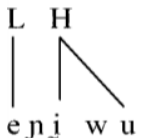

L $\mathrm{H}$
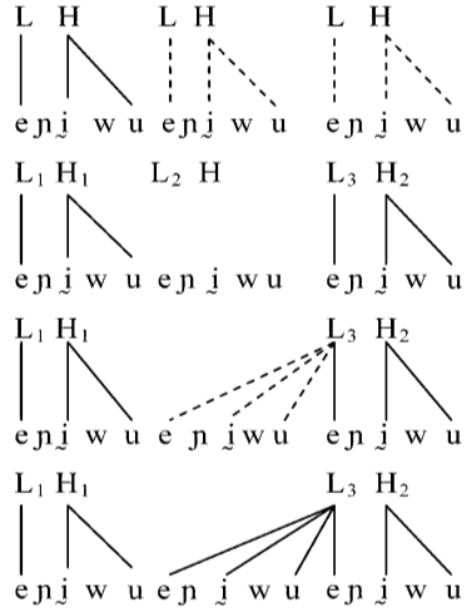

Underlying Representation

Simultaneous Copying/Cloning

Middle Token Tone Erasure

Leftward Spread of $\mathrm{L}_{3}$

OCP/Derived Output

[èníwé-èniwè-èníwú]

We build the second theory on the oft-quoted hypothesis adopted in this paper, that is, the reduplicant does not copy the tone of the base. Hence, being toneless, each copy may either receive the default L or polarize with the tone of an adjacent token in the reduplicated structure. It is a generally acknowledged fact that all morphemeinitial vocalic segments in Akan (i.e., all nominal, verbal, adjectival, and postpositional prefixes in Akan) are intrinsically toneless. Hence, other things being equal, a root morpheme-initial syllabic segment in Akan receives the default $\mathrm{L}$ at the p-level. So, here, when the adjective base reduplicates, the first copy or reduplicant may either polarize with the base $\mathrm{H}$ or take the default L. However, a second copy or the retriplicant located to either the right or left of the base also polarizes with the tone of the preceding token, that is, whether the direction of tone copying is rightwards or leftwards. Let us study 
24 On Tone and Morphophonology of the Akan Reduplication Construction

the derivation below for graphic illustration assuming that the direction of copying begins from the left to the right:

(8)

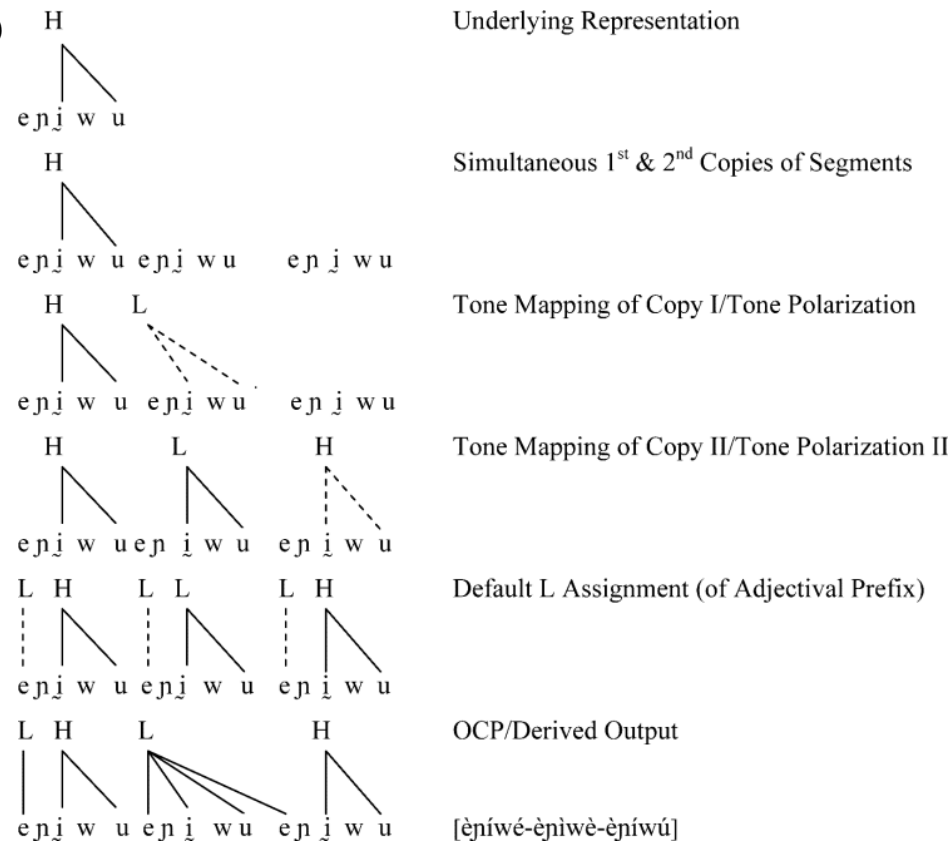

If the direction of copying were to be leftwards the derived output would be the same as above. On the strength of the forgoing accounts or theories, it would be impossible to establish the base, the reduplicant or the retriplicant.

\subsection{Toneless Adjectives}

Some adjectives in Akan are toneless in that they are unspecified for tone at the $\mathrm{u}$-level; therefore, they receive $\mathrm{L}$ by default at the $\mathrm{p}$ level (Abakah 2005a, 2010; Abakah, Caesar \& Ababila 2010). Two 
types of toneless adjectives are distinguishable in Akan. One type ends in a non-vowel sonorant preceded by a short vowel whereas the other type ends in a long $\mathrm{V}$. These undergo diverse morphophonological processes when they reduplicate and so we study them separately even though in tonological terms, the TBUs of all affixal elements in the reduplicative formation bear the default $\mathrm{L}$.

\subsubsection{Toneless Adjectives: Type I}

As we have observed in our study of Akan reduplication construction so far, once the segmental melodies of a base have been copied, phonological rules operate to fine-tune them for the p-level. Let us examine data (9) below for illustration:

\begin{tabular}{|c|c|c|c|c|}
\hline (9) & Adj. & Gloss & RED I & RED II (RETRIP.) \\
\hline i. & fहw & beautiful & fèć-féẃ & 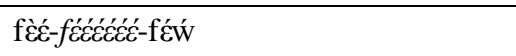 \\
\hline ii. & ntcin & salty & j̀̀tcìn-j́tcIñ & 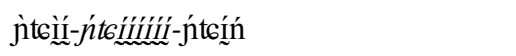 \\
\hline iii. & nuin & cold & nuìí-nчíń & 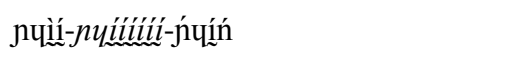 \\
\hline is & dzIn & strong/hard & dzilı́-czĩń & dziÌ-dzi!IIIIIII-dzIńn \\
\hline & har & light & hàá-háŕ & hàá-hááááááa-háŕ \\
\hline & gow & soft & gòứ-gứw & gòứ-gươơơớ̛́-gưw / gòứ-gwíiIIIIII-gứ \\
\hline & tor & slipery & tòư-tớŕ & tòú-tớ̛̛̛́́์̛ớ-tớr'/ tùú-tyiIIIIIIII-tứr \\
\hline iii. & dur & heavy & dùú-dúŕ & dùú-dúúúúúu-dúŕ / dùú-dyíîíííi-dúŕ \\
\hline
\end{tabular}

Before we comment on the tonal perturbations associated with reduplication of these toneless adjectives, let us study interesting morphophonological processes that operate during their construction. To begin with, the alternative post-slash outputs of (9vi-viii) present a case of overapplication of reduplication in that a high front $\mathrm{V}$ is 
epenthesized between the initial syllable of the middle token and the following syllable, as the set of rules below illustrates:

\begin{tabular}{|c|c|c|c|}
\hline Base ( 3 copies) & \#tortortortor\# & \#grwguwgowgow\# & \#ckIndzındzındzıIn\# \\
\hline $\begin{array}{l}\text { Nonfinal token V- } \\
\text { spread }\end{array}$ & \#toutuotuotor\# & \#guvguoguvgow\# & \#dkIIIkIIdZIIIGIIn\# \\
\hline $\begin{array}{l}\text { Palatal high V- } \\
\text { epenthesis }\end{array}$ & \#toutoituotor\#\# & \#guvguıguvguw\# & \#ckIIdkIIdkIIdzIn\# \\
\hline Glide formation & \#tuot ${ }^{\mathrm{t}}$ Ituotur\# & \#guovg"Igouguw\# & - \\
\hline $\begin{array}{l}\text { Epenthesized V- } \\
\text { spread }\end{array}$ & \#tuot' ${ }^{\mathrm{I}} \mathrm{IIII}$ tor\# & \#goug ${ }^{\mathrm{w}}$ IIIIIgow\# & 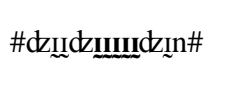 \\
\hline Derived output & [tout ${ }^{\mathrm{I}} \mathrm{IIIIIt}$ r] & [govg ${ }^{\mathrm{w}}$ IIIIIgow] & [dzIIck!mdz!n] \\
\hline
\end{tabular}

The V-Place [CORONAL] articulator feature inherent in the epenthesized $\mathrm{V}$ conditions the preceding labial $\mathrm{V}$ anticipatorily to devocalize into a labial palatal glide if the $\mathrm{C}$ preceding the target $\mathrm{V}$ is specified as [CORONAL]. But where the $\mathrm{C}$ in question is [DORSAL] or [LABIAL], the epenthesized $\mathrm{V}$ devocalizes into a labial velar glide, /w/. After the application of the glide formation process, the epenthesized vowel spreads rightwards through all the following segments up to the left boundary of the final token of the entire reduplicative construction. In (10) above, we have summarised the phonological rules that operate on the base and its copies to generate the final output, in the order in which they operate.

It is perceptible from data (10) that the stem vocalism invariably spreads to the stem-final nonvocalic sonorant, except for the rightmost element which is not spared in most Fante varieties. For instance, har and fEw meaning light and beautiful reduplicate/ retriplicate in the Boka variety of Fante as hàá-há / hàá-hááááá-há

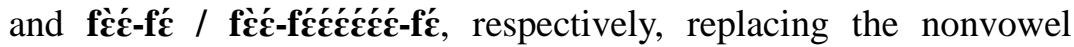
sonorant with the base-final vocalism not only in the reduplicative 
base but also in the copies. The reduction in the final vowel of the rightmost token of the reduplicative construct confirms the fact that the copy elements are attached to the base which is the leftmost token $^{7}$ on the right.

In terms of tonology, the bases in (9) under RED I, being toneless, are all realized on $\mathrm{L}$ at the $\mathrm{p}$-level with a slight modification brought about by post-mapping tone sandhi process. After the base has characteristically received the default $\mathrm{L}$, the reduplicant takes an opposite tone, the $\mathrm{H}$. After the application of the tone polarization process, the reduplicant's / right token's H spreads leftwards across the token boundary to the preceding base-final sonorant and replaces its $\mathrm{L}$ acquired by default. The displaced $\mathrm{L}$ is absorbed by the $\mathrm{L}$ of the initial TBU of the base, the left token. Under RED II, the retriplicant is sandwiched between the leftmost and the rightmost elements of the output of RED I. Unsurprisingly, it takes the $\mathrm{H}$ of the surrounding TBUs and is therefore produced on $H$. (11) below captures this analysis graphically.

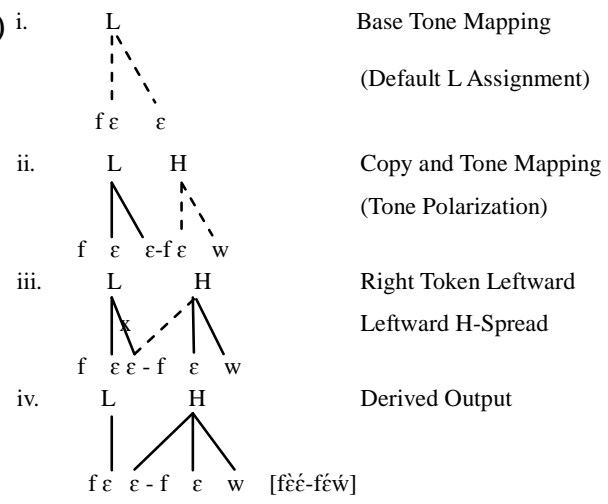

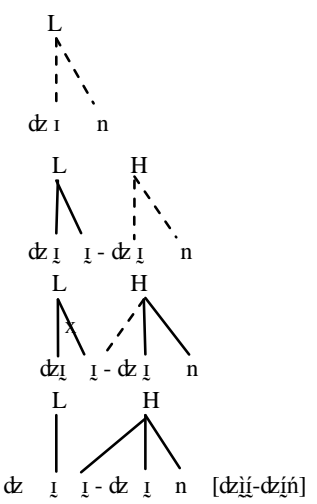

dz $\underset{\sim}{\mathrm{I}} \underset{\sim}{\mathrm{I}}-\mathrm{dz} \underset{\sim}{\mathrm{I}} \mathrm{n} \quad$ [dìî-dzíń]

\footnotetext{
See Abakah (2003a) for a detailed study of the phonological processes that operate on the base and the copied units to generate the final output.
} 
The output tone melody could also be analysed as the direct result of postcopy mapping where the tones carried by the TBUs of the disyllabic constituents of the leftmost token polarize; as the initial TBU takes $\mathrm{L}$, the second TBU takes $\mathrm{H}$. Thereafter, the $\mathrm{H}$ spreads rightwards through to the rightmost boundary of the entire reduplicative construction. Based basically on principles of association condensed in the foregoing brief analysis, we can capture this account vividly as (12) demonstrates. ${ }^{8}$ Here, the base and all the copies are assigned just an LH melody mapped and spread as (12):

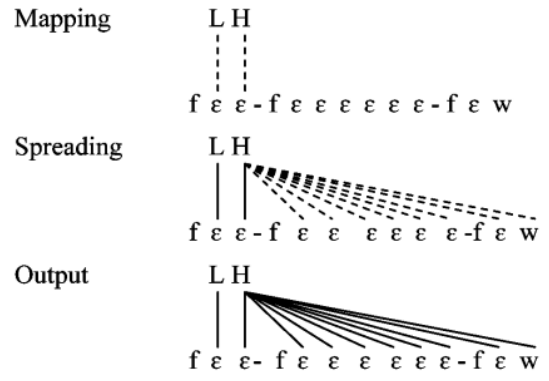

[fèć-féććććć-féẃ]
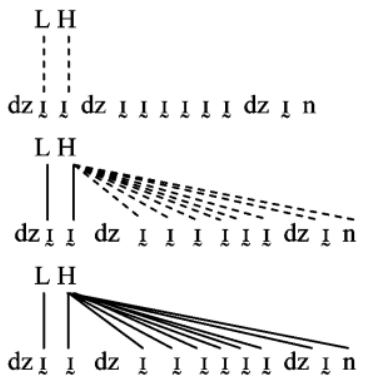

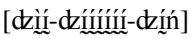

The above graphic account clearly captures the application of the principles of mapping and spreading to generate the final output. In

${ }^{8}$ To refresh readers' memory, we repeat the principles of mapping and spreading in the words of Durand (1990: 249) as follows:

"Mapping: Associate vowels with tones in a one-to-one fashion from left to right until we run out of tones or vowels.

"Spreading: If after applying mapping some vowels are still free link them to the last tone on the right."

We modify these two principles of association by replacing vowels with TBUs inasmuch as vowels are not the only segments that bear tones in Akan. Glides, depending upon phonetic environment in which they occur, are also tone-bearing in Akan. 
this context, it is difficult to settle on the sites of the base and the reduplicant even though the site of the retriplicant is indisputably the middle token of the entire reduplication construction.

\subsubsection{Toneless Adjectives: Type II}

Toneless adjective type II ends in a long/double V each of which is syllabic and redundantly a TBU. These abound in the Akan language and, like the other types of the adjective in Akan, their segmental melodies are cloned when reduplicated as exemplified by (13):

\begin{tabular}{|c|c|c|c|c|}
\hline$(13$ & Toneless adj. & Gloss & RED I & RED II \\
\hline i. & pikaa & thick (said of fluids) & pìkà-píkà̀à & pìkà-pìkà-píkàà̀ \\
\hline ii. & sokoo & rosy (said of life) & sòkò-sókòò & sòkò-sòkò-sókòò \\
\hline iii. & trokaa & slippery & trò̀kà-tŕò̀à̀a & trò̀kà-trioùà-tŕùkà̀à \\
\hline 1V. & petcec & loose/muddy & pètcè-pétcèc̀ & 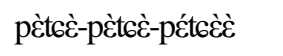 \\
\hline & bojaa & slow/depressed & bònà̀-bónàà & bònà̀-bònà̀-bónà̀à \\
\hline vi. & soteII & oily (said of foods) & sòtcì-sótcì̀ & sòtcì-sòtcì-sótcì̀̀ \\
\hline vii. & mơsర్ల్ర & melancholy & mòsù-mớsర̃̀̃ & mùsù-mùsò-mớsừ \\
\hline & betec & weak/soft & bètè-bśtč̀̀ & bètè-bc̀tè-bćtècे \\
\hline & potos & dirty & pòtò-pótò̀̀ & pòtò-pòtว̀-pótว̀̀̀ \\
\hline & kusuu & $\operatorname{dim}$ & kùsù-kúsùù & kùsù-kùsù-kúsùù \\
\hline
\end{tabular}

The long $\mathrm{V}$ inherent in the base is always shortened in the reduplicant as well as the retriplicant. Nevertheless, it is not straightforward to determine the phonetic environment in which the retriplicant is sited. Is it located in the boundary between the base and the reduplicant of RED I or prefixed to the derived output of RED I, seeing that the leftmost and the middle tokens are realized on identical segmental and tone melodies? 
Be that as it may, the initial TBU of the rightmost element bears an $\mathrm{H}$ otherwise all the TBUs in the entire reduplicative construction would be produced on L. This is diametrically opposite to that of toneless adjectives type I by which all the TBUs would have been $\mathrm{H}-$ toned had it not been for the L on the initial TBU of the output. In type II adjectives under RED II, the rightmost token is the base inasmuch as it contains all the segmental melodies of the base as well as the inherent prosodic feature of nasality which, other things being equal, is not copiable in the Akan reduplication construction.

It is interesting to note that tone polarization occurs in both types of adjective in the base. However, the striking tonal differences between the outputs of types I and II adjectives reside in the fact that in type I, the second TBU of the base, the leftmost token, takes an $\mathrm{H}$ in polarity with the default L of the initial TBU. The polar tone then runs through all the TBUs in the reduplication construction. In type II, on the other hand, the initial TBU of the base, the rightmost token, also takes an $\mathrm{H}$ in polarity with the default $\mathrm{L}$ of the preceding and the following TBU(s). Finally, in type I, the default L turns out to be the only $\mathrm{L}$ in the entire output whereas in type II, the polar $\mathrm{H}$ remains the odd tone in the entire reduplication construction. Thus, in the toneless adjective type I, all the copies are consistently attached to the base on the right whereas in type II, all the copies are regularly attached to the base on the left. In the cause of easy reference let us look at two examples from each type as (13').

\begin{tabular}{|c|c|c|c|c|}
\hline Type & Toneless adj. & Gloss & RED I & RED II \\
\hline Type I: & i. har & light & hàá-háŕ & hàá-háááááá-háŕ \\
\hline & ii. $f \varepsilon w$ & beautiful & fècéff́ćẃ & 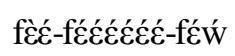 \\
\hline Type II: & i. pika & thick (fluid) & pìkà-píkà̀à̀ & pìkà-pikà-píkà্à \\
\hline & ii. sokoo & rosy (life) & sòkò-sókòò & sòkò-sòkò-sókòò \\
\hline
\end{tabular}




\section{Reduplication of Nouns}

Reduplication of nouns in Akan operates on principles which are practically identical with those found in reduplication of verbs and adjectives but with some differences. Both singular and plural nouns may be reduplicated in Akan, as data (14) and (15) below illustrate.

\begin{tabular}{|c|c|c|c|c|c|}
\hline (14) & Noun & Gloss & Plural/Base & RED & Gloss \\
\hline i. & bùsứ 'm & month & à-bùsư' ḿn & àbùsứ ḿn- àbùsớ 'm & many months \\
\hline ii. & kư!kú & hill & à-kứkú & $\begin{array}{l}\text { àkúkư-àkư 'kú/ } \\
\text { àkưkù-à kứ kú }\end{array}$ & $\begin{array}{l}\text { many hills / } \\
\text { hilly }\end{array}$ \\
\hline iii. & ò-wú & death & - & $\begin{array}{l}\text { è-wù-wù-wú-'wú / } \\
\text { èwù-wùí-'wú }\end{array}$ & (many) deaths \\
\hline iv. & àǹgứá & oil & - & $\begin{array}{l}\text { àǹgơá-áńgớá/ } \\
\text { àǹgưà-áńgứá }\end{array}$ & oily \\
\hline v. & j̀t6íń & salt & - & 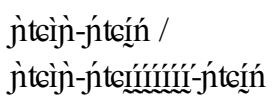 & $\begin{array}{l}\text { salty / } \\
\text { awfully salty }\end{array}$ \\
\hline vi. & póẃ & knot & à-póẃ & $\begin{array}{l}\text { à-póẃ-á'póẃ / } \\
\text { àpòẁ-ápóẃ }\end{array}$ & knotty \\
\hline vii. & bèjíń & male/man & m̀-bèjìṁ-fú & bèním-bènín & tomboyish \\
\hline viii. & bèsíá & female/woman & m̀-bèsìà-fứ & bèsíé-bèsíá & effeminate \\
\hline ix. & àmáń & mucus & - & $\begin{array}{l}\text { àmàn-ámáń / } \\
\text { àmáḿ-máń }\end{array}$ & mucous \\
\hline
\end{tabular}

Whereas reduplicated plural nouns essentially emphasize the plurality of the noun or quantify the noun (Dolphyne 1988), as in (14i-iii), the reduplicated singular noun invariably changes its word class into an adjective, as in (14iv-ix). This is not to obscure the fact that some reduplicated plural nouns could function as adjective (as 
32 On Tone and Morphophonology of the Akan Reduplication Construction

exemplified by the post-slash form in (14ii)). Temporal nouns, when reduplicated, function differently as illustrated by (15) below:

\begin{tabular}{|c|c|c|c|c|}
\hline$(15$ & Temp. noun & Gloss & RED form & Gloss \\
\hline i. & ànàpá & morning & ànàpá-ánàpá & only in the mornings \\
\hline ii. & èuìàbíŕ́ & afternoon & èuìàbiír-éuìàbiír & only in the afternoons \\
\hline iii. & èyìmbiî́r & evening & èuìmbbír-éuìmbjî́r & only in the evenings \\
\hline iv. & ànà̀fá & night & ànàfá-ánà्áá & only at nights \\
\hline v. & dákớŕ & one day & dákù-dákưór & once in a while \\
\hline vi. & dàpéń & week & dàpćń-dàpćń & weekly / once in a week \\
\hline vii. & bùsớ'ḿ & month & bùsứ'm-bùsứ'ḿ & monthly/once in a month \\
\hline viii. & àfî̀ìá & one full year & àffî̀iá-àfग̂cì̀ & every year / once a year \\
\hline & àfjí & year & àfór-áffí & year on year \\
\hline
\end{tabular}

A reduplicated temporal noun (15i-viii), for instance, functions as an adverbial which consistently indicates that the action encoded by the verb it modifies happens routinely. However, if a temporal noun reduplicates in its plural form as in (15iii) the plurality of the noun is amplified and/or quantified. To facilitate reference, let us repeat here an example from (15), bơsớ'ḿ 'a month' whose plural form being àbòsớ' 'months,' reduplicates as àbòsớ m-ábòsớ'ḿ to mean 'many months.'

The briefest inspection of the above data (14) and (15) reveals the fact that segmentally, some nouns undergo total reduplication. In (14i, iv, v-ix), for instance, since both the segmental and tone melodies are identical, it is totally impracticable to tell between the base and the reduplicant. Downstepping occurs in a number of outputs due to tone sandhi rules. In the pre-slash forms of (14iii, iv, vi) and (15ix), for instance, the $\mathrm{H}$ of the left token spreads to the initial $\mathrm{L}$ of the right 
token of a base and dislodges it. The dislodged L floats between its original TBU and the $\mathrm{H}$ of the following TBU(s) to cause all the TBUs following it to receive a downstep $\mathrm{H}$. This account is captured graphically by (16) below:

(16)

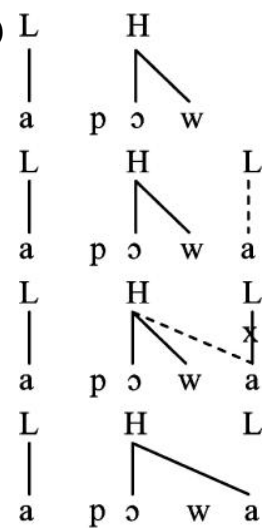

Underlying Representation

Base Cloning

Rightward $\mathrm{H}_{1}$-Spread

Across Element Boundary

Resyllabification/w-Onsetting

Derived Output

[àpów-á'póẃ ]

In the alternative, post-slash outputs in (14), the segmental melodies are copied minus tones as (16) captures graphically. Hence, the reduplicant receives the default $\mathrm{L}$. However, the $\mathrm{H}$ of the base spreads to the prefixal, toneless plural formative at the base-initial position. The following derivation presents a graphic representation of the above account: 
34 On Tone and Morphophonology of the Akan Reduplication Construction
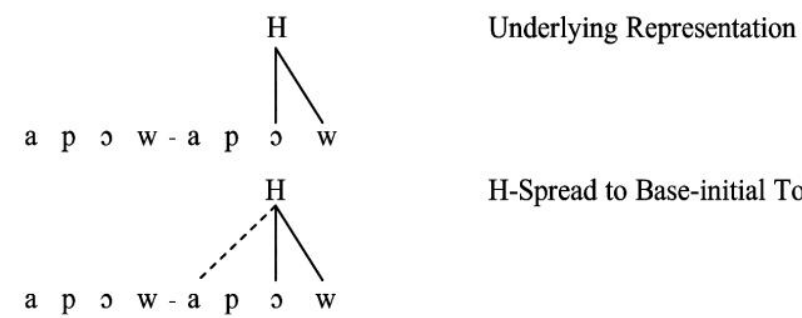

H-Spread to Base-initial Toneless TBU

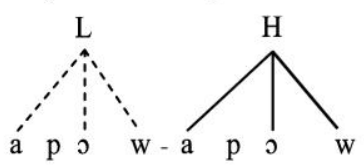

Default L Assignment
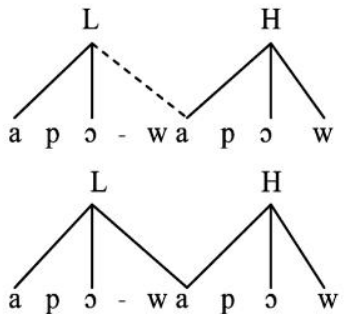

Derived Output

[àpò-wăpóẃ]

It is clear from (17) that when a base begins with an onsetless $\mathrm{V}$ syllable and ends in a nonvowel syllabic sonorant (S), a heterosyllabic $\mathrm{S}-\mathrm{V}$ sequence occurs at the boundary between the leftmost and the rightmost tokens of the reduplicated form, as (14i, vi, ix) and (15ii, iii) demonstrate. The $\mathrm{S}$ and $\mathrm{V}$ become tautosyllabic through resyllabification to onset and nucleus positions, respectively. The $\mathrm{S}$ loses its TBU status in the left token and its default L cosettles on the nucleus of the new syllable with the spreading $\mathrm{H}$ to generate the final output.

Bases of temporal nouns as in (15i-ix) copy both the segmental and tone melodies once with various segmental modifications and tonal perturbations, thereby redundantly producing only two tokens in the entire reduplicative structure. Some phonological processes 
identical to those we have discussed above occur at the boundary between the two tokens of the reduplicative output. Besides, where a base begins with a $\mathrm{C}$ and ends in an $\mathrm{S}$, a $\mathrm{CC}$ sequence unattested in any of the varieties of Akan, occurs thereby eliciting the truncation of the $\mathrm{S}$. The base in $(15 \mathrm{v})$, for instance, is dák kór, which when reduplicated, dákòredá'kóŕ is generated causing unattested r-d of a $\mathrm{CC}$ sequence to occur at the boundary between the base and the reduplicant. The $/ \mathbf{r} /$ has to be truncated to yield the derived output dákò-dá'kớr in full satisfaction of the phonotactics of Akan.

In terms of tonology, even though the initial $\mathrm{V}$ of the base is Ltoned, the initial tone of the right token of the reduplicated output is realized on an $\mathrm{H}$. This gives credence to our theory that all nominal prefixes in Akan are toneless. It, therefore, comes as no surprise that all nominal prefixes in Akan take the tone of the preceding tokenfinal $\mathrm{H}$. However, where the temporal noun does not have a nominal prefix but terminates in a nasal $\mathrm{C}[\mathrm{m} / \mathrm{n}]$, both the segmental and tone melodies are cloned, as in (15vi, vii) which we present below as (18) to facilitate reference.

\begin{tabular}{lllll} 
(18) & Temp. noun & Gloss & RED form & Gloss \\
\cline { 2 - 4 } i. & dàpéń & week & dàpéń-dàpéń & weekly / once a week \\
ii. & bòsớ 'm & month & bòsớ'm-bùsớ'm & monthly / once in a month
\end{tabular}

Finally, in bases with inherent/underlying downstep $\mathrm{H}$, if the base terminates in a nasal $\mathrm{C}$ then the entire base might be duplicated in the reduplicant as in (15vi-vii) or (18i-ii) above. However, where the base does not end in a nasal $\mathrm{C}$, but any other nonvowel $\mathrm{S}$ that does not create any unattested $\mathrm{CC}$ sequence at the boundary between the base and the reduplicant, the lexical floating $\mathrm{L}$ that conditions downstepping of the following $\mathrm{H}$ in the left element, spreads 
rightwards to dislocate the following linked $\mathrm{H}$ in that element as exemplified by $(15 \mathrm{v})$, dá'kóŕr. We graphically account for this tonal process with the following derivation (19).
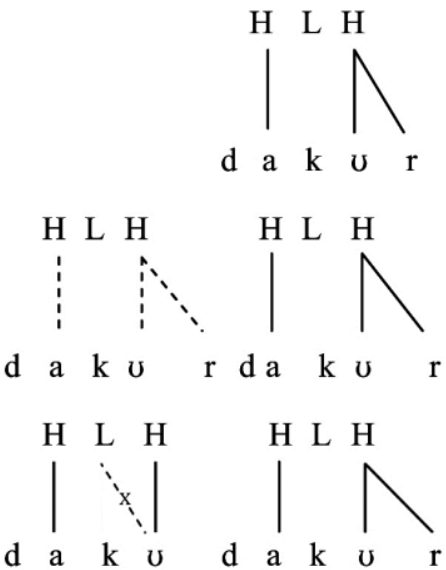

S/r-Truncation Plus

Reduplicant Floating L-Spread

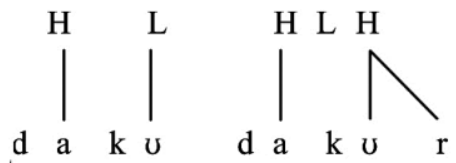

In (19), after the base/UR has reduplicated by way of copying both its segmental and tone melodies, the SC sequence created at the boundary between the base and the copy is simplified through truncation of the $\mathrm{S}$. The floating $\mathrm{L}$ in the reduplicant then spreads rightwards to dislodge the $\mathrm{H}$ on its right thereby eliminating the downstep in the output reduplicant.

\subsection{Reduplication of Deverbal Nouns}

Through the process of nominalization, a verb in Akan can be 
transformed into a noun but the tonal perturbation it might undergo would depend principally on the class to which it belongs (Abakah 2005b). Transforming a class I or III verb root (VR) into a noun educes prefixation of a toneless vocalic nominal formative to the VR which does not undergo any tonal perturbation. However, if a class II verb undergoes nominalisation, none of its underlying segmental melodies goes through any alternation, albeit its lexical tone melodies undergo perturbations. (20) exemplifies nominalisation of verbs and their reduplicated forms. (20i-iii), (20iv-vi), and (20vii-ix) represent examples of nouns derived from classes I, II, and III verbs, respectively, plus their reduplicated forms.

\begin{tabular}{|c|c|c|c|c|}
\hline (20) & Verb & Gloss & Deverbal noun & Reduplicated form \\
\hline i. & sáẃ & to dance & à-sáẃ ‘dancing’ & - \\
\hline ii. & tớm & to insult & ń-tớm 'insult' & - \\
\hline ̈iji & sú & to weep & ò-sú 'weeping' & - \\
\hline & bísà & to ask & bí'sá 'asking' & è-bìsà-bí'sá 'investigating \\
\hline & kásà & to speak & (j)-ká'sá ‘speaking’ & à-kàsà-ká'sá 'wrangle' \\
\hline & dáǹ & to change & dá'ń 'changing' & à-dàǹ-dắń 'the act of changing' \\
\hline & teìré & to teach & j-tcìré 'teaching' & à-tcìrè-tcí' ré 'the act of teaching' \\
\hline & sòmá & to send & ò-sùmá ‘sending' & $\begin{array}{l}\text { à-sùmà-sú 'má 'the act of sending } \\
\text { someone on (an) errand(s)' }\end{array}$ \\
\hline & sùmá & to hide & ò-sùmá 'hiding' & è-sùmè-sú'mã 'the act of hiding' \\
\hline
\end{tabular}

More often than not, nouns derived from Class I verbs do not undergo reduplication in Akan, which fact is discernible from (20iiii). However, nouns derived from Classes II and III verbs do reduplicate and, like regular nouns in the language, they do not reduplicate more than once. It is invariably the plural forms of these 
nouns that serve as the base for reduplication. Nouns derived from class II verbs, as illustrated by (20iv-vi), do not regularly take nominal prefix but their reduplicated form indicates that the plural morpheme is prefixed to the left token of the entire reduplicative structure. Like the regular nouns, their reduplicated forms emphasise the plurality or quantification of the noun.

Interestingly, even though classes I and II verbs are produced on $\mathrm{HL}$ and $\mathrm{LH}$, respectively, nouns derived from them are produced on identical tone melodies when reduplicated. This presents a remarkable tonological difference between reduplication of the regular nouns and the derived ones in Akan. Moreover, the reduplicant which is prefixed to the base is redundantly produced on the default $\mathrm{L}$ whilst the base tone melody does not receive any perturbation. Hence, it is straightforward to tell between the base and the reduplicant. It is fascinating to note that in the case of reduplication of the verb, the reduplicants of the classes II and III verbs are invariably suffixed to the base as noted above. However, the reduplicants of nouns derived from these verbs are invariably prefixed to the base.

\section{Lexical Reduplication}

Lexical reduplication refers to lexically reduplicated stems which do not have any related unreduplicated stem attested in a language. In Akan abound such lexemes which do not only cut across all word classes but are also subcategorizable into two types. 


\subsection{Lexical Reduplication Type I}

The data below, extracted from verbs, adjectives, and nouns only, illustrate type I of lexical reduplication:

\begin{tabular}{|c|c|c|c|c|c|c|}
\hline (21) & Verb & Gloss & Adjective & Gloss & Noun & Gloss \\
\hline i. & sù-sú & to measure & gíczí-gíczí & impetuous & m̀nà-m̀pá & pap \\
\hline ii. & s̀̀-sá & to change & pósó-pósó & senile & ỳ-kớn-ý'kóń & cough \\
\hline iii. & sì-sí & to cheat & népú-nếpú & very dirty & sí-sí & bear \\
\hline iv. & sì-sí & to calculate & húńtú-húńtú & pulverised & sá-sáw & lobster \\
\hline v. & tờǹ-tớń & to praise & króý-króń & holy & Mừó-Mòró & kidney \\
\hline vi. & kờ̀-kơńn & to hang about & dókó-dókó & sweet & dókò-dókò & duck \\
\hline vii. & fìm-féń & to challenge & déteć-dćté́ & delicious & ǹtsé - 'tsé & ants \\
\hline viii. & pìć-pìc̀ẁ & to analyse & dá-'dá(ẃ) & old & súń-'súm & spirit \\
\hline ix. & ${ }^{n}$ Mừnéd- ${ }^{n}$ Mù̀nà & to frighten & fư-'fớr & new & kú-kúẃ & stump \\
\hline $\mathrm{x}$. & tsìi-tsì̀ & to worry & frèkù-frèkù & grubby & fi-fír & sweat \\
\hline xi. & tsì-tsí & to train & tsì-tsì & ancient & kòó-kòó & piles \\
\hline xii. & dàá-dàà & to deceive & kóbú-kóbú & smooth (skull) & só-sóẃ & axe \\
\hline xiii. & nừ-nứ & to tickle & tsí-'tsín & important & pà-pá & frond \\
\hline xiv. & hàá-hàà & be distressed & ${ }^{\mathrm{\eta}} \mathrm{w} \mathfrak{\sim}^{-}-{ }^{! n} \mathrm{wá}$ & wonderful & ká-'ká & a crack \\
\hline
\end{tabular}

With the exception of the noun in the above data, the verb and the adjective can be further reduplicated as long as the breadth would allow as in péńsà-pèǹsà-pèǹsà-pèǹsà-pè̀̀sà mú (verb: 'to examine exceedingly thoroughly’) and dókó-dókó-dókó-dókó-dókó-dókódókó-dókó-dókó-dókó (adjective: ‘extremely sweet beyond belief’). In the former example, it is obvious that the initial token, on the strength of the tone melody of the construction, is the base whereas all the suffixal tokens are copies of the base. In the latter example, on 
the other hand, it is absolutely impossible to tell the base and the reduplicant apart since the segmental and tone melodies of the base are absolutely cloned. It is also evident from (21) that bases and reduplicants do not have fixed sites inasmuch as the reduplicant is either prefixed or suffixed to the base.

\subsection{Lexical Reduplication Type II}

The type II of lexical reduplication's construction does not harmonize with the reduplication paradigm attested in the language. A brief examination of all the previous examples, irrespective of word class, reveals that Akan operates complete reduplication category by which the entire segmental melody of the base is copied, followed by application of phonological rules that simplify consonantal or vocalic sequences unattested in the language at the juncture between the base and the reduplicant. However, type II of lexical reduplication is of the partial variety that copies only a syllable or two from the base and erases all unlicensed material. For this reason, we can effortlessly determine not only the base and the reduplicant but also the affixal location where the constituent tokens of the reduplication structure are sited. Whereas some of the reduplicants are prefixed, others are suffixed to the base. Observe that as the tone of some licensed material polarizes its tone with that of the base, others copy the tone of the base. Let us examine data (22) for illustration noting that lexemes belonging to the various word classes are mixed up in line with our focus in terms of determining the affixal site of the base and the reduplicant. 


\begin{tabular}{|c|c|c|c|c|}
\hline (22) & $1^{\text {st }}$ Token base & Gloss & $2^{\text {nd }}$ Token base & Gloss \\
\hline i. & fínìm-fiń & middle & kò-kòbú & weasel \\
\hline ii. & kàtsín-kà & giant/giantess & pà-pàtsìr & type of children's game \\
\hline iii. & kwátsiŕr-kwá & a destitute person & kwàá-kwàánà̀m ${ }^{\mathrm{y}}$ wá & shell of an octopus \\
\hline iv. & bùrò-bú & testicles & kwàá-kwàádèbí́ & crow (bird) \\
\hline v. & kàkr̀à-ká & big & dư-dưbéń & a species of plant \\
\hline vi. & sứp'I'ŕr-'pi' & type of plant & tsìn-tsímbjì̀̀ & ginger \\
\hline vii. & kòkòdú-dú & a species of fish & kj̀-kòtučí & a species of fish \\
\hline viii. & kwàà6uí-6uí & a man of straw & kòǹ-kòǹsá & gossip \\
\hline ix. & kùsùkùú-kùú & a thick fog/mist & tsì-tsiàǹnódóŕ & amulet \\
\hline $\mathrm{x}$. & súpúr-pú & river turtle & kj̀-kj̀tsí & warthog \\
\hline
\end{tabular}

Forms under " 1 st $T$ Token base" and " $2^{\text {nd }}$ Token base" do suffix and prefix, respectively, their respective reduplicants to the base. Here, only part (usually a syllable or a disyllabic piece) is copied and the unlicensed material chopped off. Let us study derivations (23) and (24) in which the mode of copying and the general reduplication construction is demonstrated graphically. 
42 On Tone and Morphophonology of the Akan Reduplication Construction

(23)
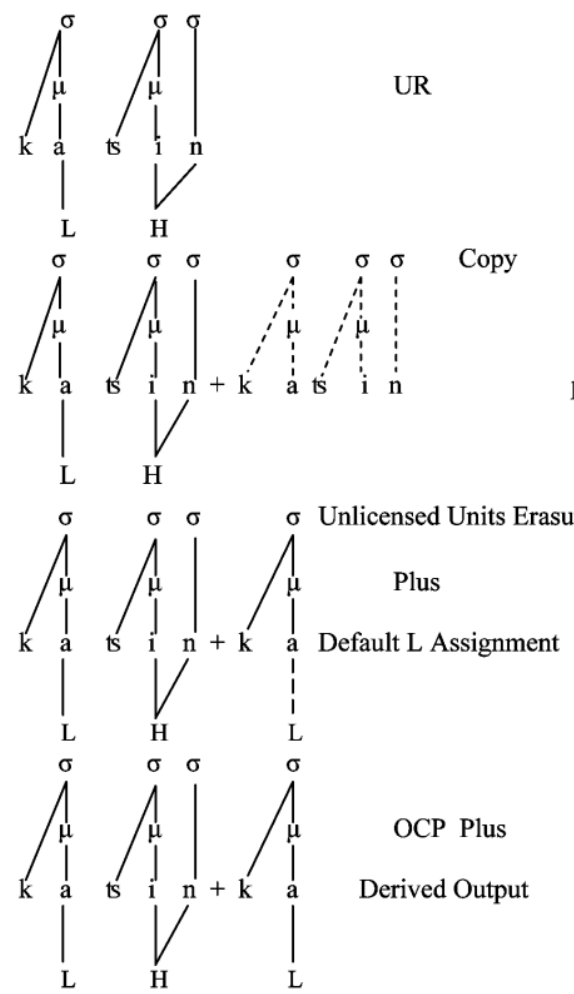

[kètsíń-kà]
(24)
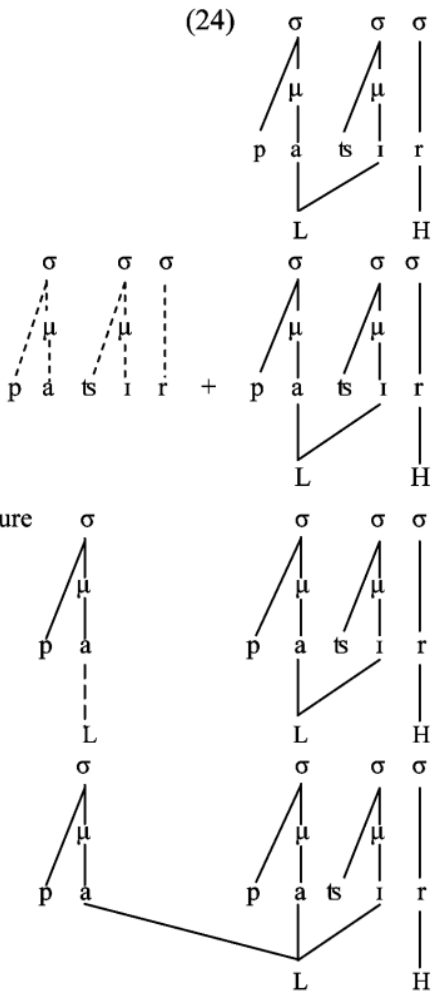

[pà-pàtsì́r]

In (23) and (24), the underlying representations display the bases with their lexical tone melodies. The next stage copies the segmental melodies minus the tone melodies. In both derivations, since it is the initial syllable only that is licensed by the templatic constraint they are retained as the reduplicant, whereas since all the syllables following or preceding the initial one (depending upon the type) are unlicensed, they are summarily weeded out of the reduplication construction. The only difference between derivations (23) and (24) is that in the former the reduplicative template is suffixed to the base 
whilst that of the latter is prefixed to the base. On the tonal front, the licensed, copiable, material receives the default $\mathrm{L}$.

It is noteworthy that in some cases, it is only the final and not the initial syllable that gets licensed by the templatic control and is therefore redundantly suffixed to the base whereas all the syllables preceding it are deleted, as (22viii-ix) under " 1 st Token base" illustrate. In such cases, the syllables close to the base are all truncated. In kwààcyí-cyí and kùsùkùú-kùú, for instance, the copy takes the following forms kwààcyí-kwààcyí and kùsùkùú-kùsùkùú, respectively. However, inasmuch as only the final syllables, -cyí and -kùú, are licensed by the templatic constraint, they do not receive any modifications even as they constitute the reduplicants in the reduplicative output. The unlicensed materials are then erased as follows:

\begin{tabular}{|c|c|c|}
\hline Copy (the Base) & \#kwààcuítkwààcuí\# & \#kùsùkùú+kùsùkùú\# \\
\hline $\begin{array}{l}\text { Truncate } \\
\text { unlicensed material }\end{array}$ & \#kwààcuí+kwààcuí\# & \#kùsùkùú+kùsùkùú\# \\
\hline Derived output & $\begin{array}{l}\text { \#kwààcuít+6uí\# } \\
\text { [kwààcyí-cyí] }\end{array}$ & $\begin{array}{l}\text { \#kùsùkùú+kùú\# } \\
\text { [kùsùkùú-kùú] }\end{array}$ \\
\hline
\end{tabular}

\section{Concluding Remarks}

In this paper, a number of approaches to reduplication construction in Akan have been considered demonstrating that whereas some principles apply across reduplication constructions, others are restricted to particular types of reduplication. It has also been demonstrated in this paper that in the Akan reduplication 
construction, the reduplicant is not invariably prefixed to the base as obtains in the existing literature. The reduplicant could be suffixed to the base depending on the word class and the class to which a particular lexeme belongs within that word class, especially in the case of verbs. We have also shown in this paper that the entire output of a reduplicative construction in Akan can serve as the base for further reduplication. In such cases, the reduplicant may be prefixed, suffixed or sited between the rightmost and leftmost tokens of the base, the output of RED I. In other types of reduplicative production, it is difficult to determine which token constitutes the base or the reduplicant because both the segmental and tone melodies of the base are cloned.

This paper has also revealed that reduplication in Akan is basically of the total type and that once copying of segmental melodies has happened, some phonological processes naturally operate on the entire reduplication construction to yield the final output. It is not only the reduplicant that undergoes segmental and tonal modifications but also the base undergoes modifications within the context of Akan phonotactics, depending upon the affixal location of the reduplicant. Segmental modifications include agreement of adjacent vocalic segments in a couple of dimensions of $\mathrm{VH}$ and simplification of junctural consonantal sequences unattested in the language by truncating the $\mathrm{C}_{1}$ to satisfy the Akan phonotactic constraints. Tonal modifications result from tonal polarization and spreading, among others. In all the foregoing reduplication patterns, all the segmental melodies are licensed to the reduplicative paradigm and, for this reason, the final outputs display total reduplication, save the phonological processes referred to.

We have also noted that Akan operates partial reduplication as well by which only the initial or final syllable of the base are copied as the 
reduplicant whereas all the remaining syllables, being unlicensed to the reduplicative parameter, are erased. This kind of reduplication resides in the history of the language and is therefore associated with lexical reduplication by which the identifiable bases have fallen into disuse in the language. Finally, in this paper, we have not captured reduplication of phrases, sentences, adverbs, and ideophones, which present interesting segmental and tone sandhi processes. These surely constitute potential topics for future study of Akan reduplication which we have shown in this paper to be a productive morphophonological process.

\section{References}

Abakah, E. 1993. Some Aspects of the Phonology of the Mfantse Dialect of Akan. MPhil Thesis. University of Ghana. . 2003a. Syllable Structure Processes in Akan. Languages and Linguistics 12, 43-63. . 2003b. The Segmental and Tone Melodies of Akan. PhD

Dissertation. Norwegian University of Science \& Technology. . 2004. Elision in Fante. Africa and Asia 4, 181-213.

. 2005a. Tone Rules in Akan. The Journal of West African Languages 32.1/2, 109-134. . 2005b. Tone in Akan Nominals. In M. Kropp Dakubu et al. (eds.), Studies in the Languages of the Volta Basin 3, 193-218. Accra: University of Ghana. . 2010. Tone and the Associative Construction in Akan. The Journal of West African Languages 37.2, 57-80. 2012. Some Assimilatory Processes in Akan. The Journal of West African Languages 39.2, 47-82. 
. 2013. Vowel Replacement Patterns in the Mfantse Dialect of Akan. Journal of Universal Language 14.2, 7-51.

Abakah, E., R. Caesar \& J. Ababila. 2010. Tonomorphology of Reduplication in Akan, Dangme, and Gurune. In M. Kropp Dakubu et al. (eds.), Studies in the Languages of Volta Basin 6 (Part II) 121-140. Accra: University of Ghana.

Amfo, N., A. Boateng \& Y. Otoo. 2007. A Comparative Study of the Morphosyntactic Properties of Adjectives in Three Kwa Languages. In M. Kropp Dakubu et al. (eds.), Studies in the Languages of the Volta Basin 4 (Part I) 60-71. Accra: University of Ghana.

Boadi, L. 2010. The Akan Noun Phrase: Its Structure and Meaning. Accra: Black Mask Ltd.

Cahill, M. 1985. An Autosegmental Analysis of Akan Nasality and Tone. Non-thesis MA Project. The University of Texas at Arlington.

Christaller, J. 1875. A Grammar of the Asante and Fante Language Called Tshi (Chwee, Twi). Basel: Basel Evangelical Society.

Dolphyne, F. 1988. The Akan (Twi-Fante) Language: Its Sound Systems and Tonal Structure. Accra: Universities of Ghana Press. Durand, J. 1990. Generative and Nonlinear Phonology. London: Longman.

Kager, R. 1999. Optimality Theory. Cambridge: Cambridge University Press.

Kalchofner, P. 2000. Stative Verbs in Twi (Akan). In H. Wolff \& O. Gensler (eds.), Proceedings of the $2^{\text {nd }}$ World Congress of African Linguistics 593-602.

McCarthy, J. \& A. Prince. 1994. The Emergence of the Unmarked: Optimality in Prosodic Morphology. In M. Gonzalez (ed.), Proceedings of the North East Linguistics Society 24, 333-379. 
Obeng, S. 1989. Advanced Level Akan Phonology: Essays in Memory of P.C. Sgt. D. M. Gyasi. Mimeograph. University of Ghana.

Odden, D. 1995. Tone: African Languages. In J. Goldsmith (ed.), The Handbook of Phonological Theory 444-475. Oxford: Blackwell. . 1996. Patterns of Reduplication in Kikerewe. OSU Working Papers in Linguistics 48, 119-149.

Owusu-Ansah, L. 1995. Reduplication in Akan and English. Asemka 8, 167-179.

Schachter, P \& V. Fromkin. 1968. A Phonology of Akan: Akuapem, Asante, and Fante. UCLA, Working Papers in Phonetics, 19.

Spencer, A. 1991. Morphological Theory. Oxford: Blackwell.

Stewart, J. 1962. An Analysis of the Structure of the Fante Verb, with Special Reference to Tone and Glottalisation. Ph.D Dissertation. University of London. 